\title{
Genotypes Environment Interaction for Seven-Week Body Weight of Poultry Breeds
}

\author{
Rabab Fathi Eldarnawi*, Salem Ali Bozrayda and Fathi Ali Attia \\ Department of Zoology, Faculty of Science, University of Benghazi, Benghazi, Libya.
}

Received: 02 March 2021/ Accepted: 15 June 2021

Doi: https://doi.org/10.54172/mjsc.v36i2.57

\begin{abstract}
This study investigated the interaction of poultry breeds $\mathrm{x}$ environment under Libyan conditions and compared with that under a temperate zone for a seven-week bodyweight. Data were collected from the weekly records during the rearing period for three grandparent breeds Hypeco, Avian, and Shaver, at Ghotsultan and Tawargha from 1986 to 2001. Traits studied were daily feed consumption, cumulative feed consumption, body weight, feed consumption ratio, and mortality. The model used to analyze the data for the rearing period was included: overall mean, the effects of location, breeds within the year, the flock, seasons, and the age. Breeds x seasons and breeds x locations interaction were found in weight at seven weeks of age. Avian showed consistent performance under both hot and cold seasons for seven weeks bodyweight (1308.3-1304.4g), while Hypeco and Shaver perform well under cold seasons but not in hot seasons in Libya. Hypeco and Avian perform less under Libyan conditions compared to temperate zone conditions, whereas Shaver performs a little better under Libyan conditions. In addition, Hypeco had lower mortality, which was about 2.84\%, compared with Avian 3.0\%, and Shaver, which was $4.38 \%$ during the rearing period. This study could conclude that the performance of grandparent breeds under Libyan conditions was affected by weather and management.
\end{abstract}

Keywords: Genotype; Poultry breeds; Interaction; Body weight; Libyan conditions.

\section{INTRODUCTION}

Local chicken production in Libya is regarded as low production because they were produced only in small scale (family) farms and lacked regular health control programs, unimproved housing, and scavenging to meet the nutritional needs. Nevertheless, local chickens are a significant protein source for consumers and a substantial source of income for poultry keepers with steadily increasing poultry produce. Environment change and animal production are related, and the effects of environmental change on livestock and poultry production are apparent worldwide (Mengesha, 2011).

Poultry growth performance is not only inherited, but it is also greatly affected by the environment (Babinszky et al., 2011). The increasing indication for $\mathrm{G} \times \mathrm{E}$ interactions in recent broilers and various suboptimal conditions confirm the need for breeding programs to improve performance under particular stressful environments (Pakdel et al., 2005). One of the primary reasons for low production in the hot tropical climate is heat stress. In poultry production, broiler growth and meat yield have been strongly and negatively affected by high ambient temperatures (Ahaotu et al., 2019; Okonkwo and Ahaotu, 2019). It appears that broiler stocks reared for a high growth rate and meat yield in optimal environments cannot entirely express their genetic potential when bred in hot climates unless their selection programs include breeding for heat tolerance (Adeyinka et al. , 2006).

*Corresponding Author: Rabab F. Eldernawi, rabab.fathi@uob.edu.ly, Department of Zoology, Faculty of Science, University of Benghazi, Benghazi, Libya. 
Due to the low performance of the local breed, many projects were established by the Libyan government to cover the increasing demand for broiler meat. These projects used standard broiler parents, selected for temperate climates, whereas Libyan weather is hot, dry, and humid during summer, moderatewarm in winter with some variations between different locations. The use of standard broiler grandparents in hot climates may respond differently to different climate and management conditions. Therefore the objective of this study was to test the interaction of three imported breeds with location and season udder Libyan conditions and compared with that under the temperate zone for seven-week body weight.

\section{MATERIALS AND METHODS}

Location : The study was conducted in two different climatic zones: in Libya, which is characterized by a subtropical climate and two projects (Ghot-Al-Sultan and Tawargha) were selected to be investigated in Libya, and in a temperate zone which is characterized by relatively moderate mean yearly temperatures, with average monthly temperatures above $10^{\circ} \mathrm{C}$ in their warmest months and above $-3^{\circ} \mathrm{C}$ in their colder months (Trewartha and Horn, 1980). Most areas with a temperate climate present four seasons, and temperatures can cause variation considerably between summer and winter (McColl, 2005). Ghot-Al-sultan is located on the east side of Libya on the width line 32 and longitude line 21 . The temperature range from 6 to $17 \mathrm{C}^{\circ}$ and 18 to $33 \mathrm{C}^{\circ}$ in winter and summer respectively. Tawargha is located on the west side, on the width line 32 and longitude line 15 . The range of temperature ranges from 9 to $17 \mathrm{C}^{\circ}$ winter and 19.57 to $29.24 \mathrm{C}^{\circ}$ in summer.

Data: Three breeds were used in the two projects simultaneously, Hypeco from 1986 to 1991, Avian from 1993 to 1996, and Shaver from 1998 to 2001. Every breed had 12 flocks in each project. Every species had Male Lines
(A and B) and female lines (C and D).

Data were collected from the weekly records for several birds for each breed during rearing, as shown in Table 1.

Table (1): Total number of birds in each breed during rearing.

\begin{tabular}{lll}
\hline \hline & Ghot-Al sultan & Tawargha \\
\hline Hypeco & 16590 & 16734 \\
Avian & 14103 & 12561 \\
Shaver & 15633 & 16699 \\
\hline \hline
\end{tabular}

In this study, the hen housing system is a Noncage system floor system. The area was divided into floor space, feed space, water space, and nests. The feed program consists of (corn $54.1 \%$ - soybean meal 19.3\% - limestone (Big) 5.34\% - Limestone(small) 3.56\% - Wheat Barn $16 \%$ - DCP $0.9 \%$ - Salt $0.3 \%$ - Lysine 0.05 Methionine $0.1 \%$ ). One-day chick provided 24hour light and then decreased gradually to reach 8 hours light and 14 hours dark. By week 18 , pullets were subjected to the 2-hour impulse to enhance sexual maturity. Under the brooders, the temperature was $35 \mathrm{C}^{\circ}$. Afterwards, the temperature may slowly decrease to $26 \mathrm{C}^{\circ}$, and an average temperature in the house of 18 to $20 \mathrm{C}^{\mathrm{o}}$. To prevent dehydration of the chicks during the first week it is important to maintain a relative humidity of $70 \%$.

Traits studied: The traits studied were daily feed consumption (DFC), cumulative feed consumption (CFC). 7 Week body weight, feed consumption ratio (FCR), and mortality.

Statistical Analysis: To test breeds interaction with location and season for body weight at seven weeks, this model included year-season, breeds, and location. The following statistical model using Stat Soft Inc (2007):

$\mathrm{Yijkl}=\mu+\mathrm{Li}+\mathrm{Sj}-\mathrm{Yk}+\mathrm{Bl} / \mathrm{Sj}-\mathrm{Yk}+\mathrm{Bl} * \mathrm{Li}+\mathrm{Bl} *$ Sj-Yk + Eijkl

Whereas:

$\mu=$ overall mean, $\mathrm{Li}=$ the effect of $\mathrm{i}^{\text {th }}$ location (fixed) i ( $\mathrm{i}=$ Ghot-Al sultan, Tawargha), $\mathrm{Sj}-\mathrm{Yk}$ 
$=$ the effect of $\mathrm{Sj}^{\text {th }}-\mathrm{Yk}^{\text {th }}$ year (fixed) $\mathrm{Bl} / \mathrm{Sj} \mathrm{Bt}^{\text {th }}$ $=$ the effect of $\mathrm{Bl}^{\text {th }}$ breed $/ \mathrm{Sj}^{\text {th }}$ season-Yk ${ }^{\text {th }}$ year, $\mathrm{Bl}{ }^{*} \mathrm{Li}=$ the interaction between $\mathrm{Bl}^{\text {th }}$ with $\mathrm{Li}^{\text {th }}$ location $\mathrm{Bl} * \mathrm{Sj}-\mathrm{Yk}=$ the interaction between $\mathrm{Bl}^{\text {th }}$ breed with the $\mathrm{Sj}^{\text {th }}$ season $-\mathrm{Yk}^{\text {th }}$ year, Eijkl=the unexplained residuals.

\section{RESULTS}

There were significant $(\mathrm{P}<0.001)$ differences in bird daily feed intake between the breeds (Table.2). Hypeo breed had higher daily feed intake compared with other breed and had higher body weight $(1569 \mathrm{~g})$ than Avian $(1501 \mathrm{~g})$ and Shaver (1533g). In contrast, Shaver had higher mortality $(4.38 \%)$ than Avian (3.0\%) and Hypeco (2.84\%) Table 2. Mean and standard error of feed traits, live body weight, and percentage of mortality for different breeds (P. Rearing Period).

Interactions between breed and locations for the bodyweight at seven-week age are presented in figure (1). The avian breed had a higher body weight (1393.83g) in the Ghot AL sultan project than the Tawargha project (1252.3g). In contrast, Shaver had a lower body weight $(1072.5 \mathrm{~g})$ in the Gout AL sultan project than the Tawargha project (1320.1g). In addition, Hypeco is quite similar in both locations.

Interactions between seasons and breeds for the body weight at seven weeks age and seasons are presented in figure (2). Shaver had a higher body weight (1274.6g) in cold seasons than in hot seasons (1106.3g). Hypeco had a higher body weight $(1314.5 \mathrm{~g})$ in cold seasons than in hot seasons (1238.1g). In addition, Avian showed quite similar body weight during all seasons. Interactions of breeds under Libyan and temperate zone for the body weight at seven weeks age are presented in figure (3). Shaver had a lower body weight (863g) (1196.05g), whereas Hypeco and Avian had a higher body weight in the temperate zone $(2350 \mathrm{~g})(2695 \mathrm{~g})$ than Libya $(1263.7 \mathrm{~g})$ (1323.06g) respectively.
Table (2): Feed consumptions and growth traits and mortality for breed during rearing Prevalence of AntiBrucella antibodies.

\begin{tabular}{lccc}
\hline \hline & Hypeco & Avian & Shaver \\
\hline FBD (g) & $79.7^{\mathrm{a}} \pm 0.76$ & $72.2^{\mathrm{b}} \pm 0.75$ & $75.7^{\mathrm{c}} \pm 0.82$ \\
Mean \pm SD & & & \\
CFB (Kg) & $3.90^{\mathrm{a}} \pm 0.15$ & $3.54^{\mathrm{b}} \pm 0.07$ & $3.71^{\mathrm{c}} \pm 0.06$ \\
$\begin{array}{l}\text { Mean } \pm \text { SD } \\
\text { Weight }\end{array}$ & $1569^{\mathrm{a}} \pm 19.8$ & $1501^{\mathrm{b}} \pm 18.7$ & $1533^{\mathrm{c}} \pm 20.9$ \\
Mean \pm SD & & $2.36^{\mathrm{b}} \pm 0.003$ & $2.42^{\mathrm{c}} \pm 0.002$ \\
FCR & $2.48^{\mathrm{a}} \pm 0.007$ & $3.0^{\mathrm{b}}$ & $4.38^{\mathrm{c}}$ \\
$\begin{array}{l}\text { Mortality } \\
\%\end{array}$ & $2.84^{\mathrm{a}}$ & 1352 & 1384 \\
$\mathrm{~N}$ & 1345 & 135 \\
\hline \hline
\end{tabular}

Means within the same row with different letters are significantly different $(\mathrm{P} \leq 0.001)$

\section{DISCUSSION}

There were significant interactions between breeds at seven weeks of body weight and seasons (figure 2). For seven weeks body weight of Avian and Hypeco breeds had more significant nonlinear interaction with seasons, while the Shaver breed had linear interaction.

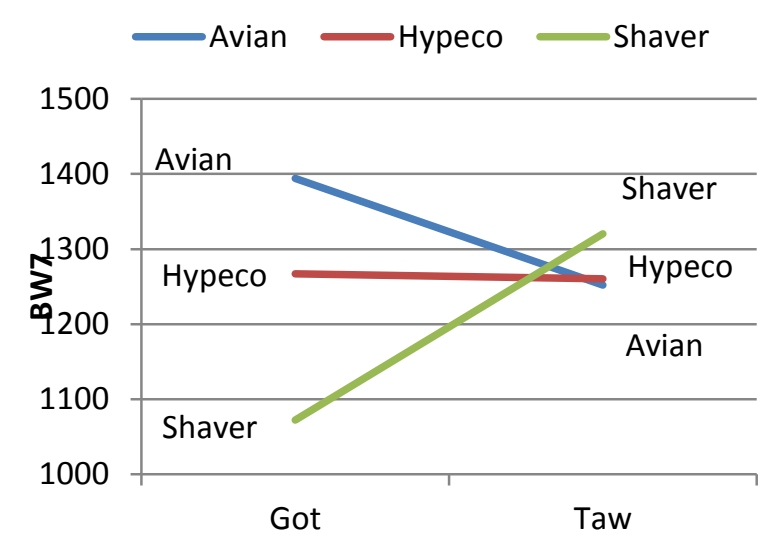

Locations

Figure (1): Breed X locations interactions for body weight at seven weeks of age. 


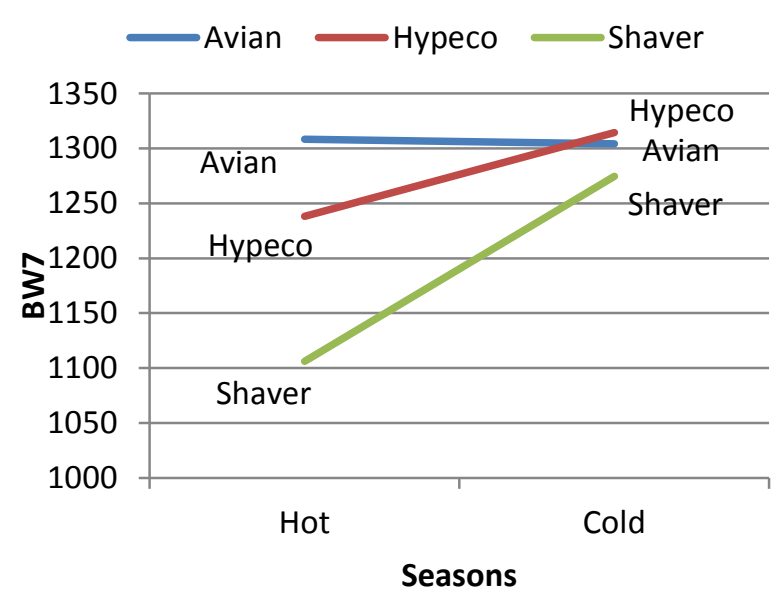

Figure (2): Breed X seasons interaction for body weight at seven weeks of age.

Avian and Shaver breeds had linear interaction. Hypeco and Shave breeds had lower body weight in hot seasons than in cold seasons. This result was in agreement with the finding of (Yalcin et al., 1997b), who concluded that a reduced body weight and body weight gain of

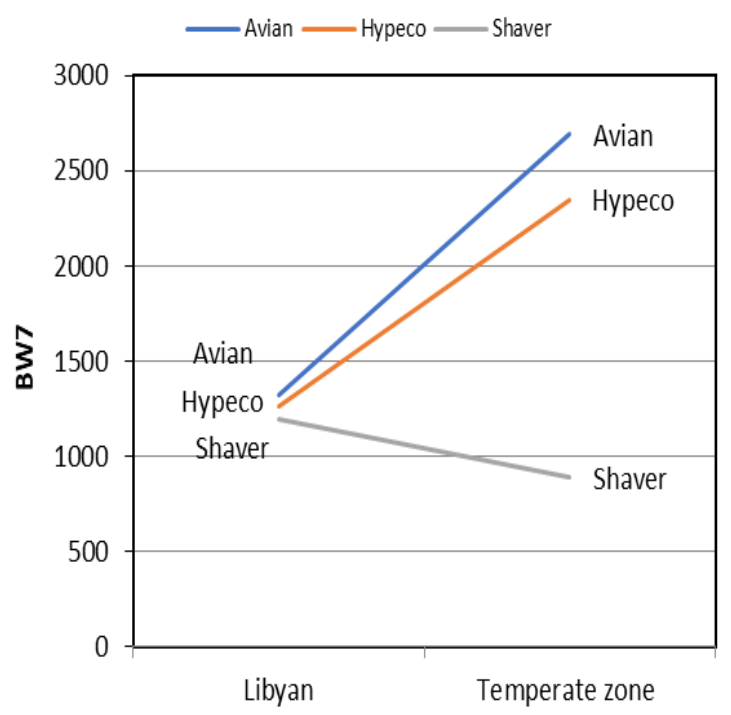

Figure (3): Evaluation of the performance of breeds under Libyan Conditions and temperate zone for seven week body weight.

about $23 \%$ and $33.5 \%$, respectively at seven weeks of commercial broilers might be due to the natural heat stress in summer. Also, (Liu et al., 2020) concluded the negative impacts of high temperature on broiler chickens regarding
BWG, FI, FCR, and mortality. The findings by (Aksit et al., 2006) also demonstrated a significantly reduced body weight in broiler chickens at 4 to 7 weeks of age at $34^{\circ} \mathrm{C}$. (Plavnik and Yahav, 1998) concluded that the bodyweight of chickens declined progressively with an increase in temperature. Hypeco breed had a constant body weight during all seasons.

In contrast, the body weight of Shaver recorded had a little bit increased during hot seasons. This result was in agreement with the finding of (Molapo, 2011) who reported that the final body weights of chickens raised in summer were heavier than those in winter despite the feeding level. Also, (Akyuz, 2009) showed that rearing birds in summer could result in higher body weight gains than birds kept in winter though the differences were insignificant. The reduced weight of birds in summer because had a low feed intake due to heat stress. The reason for variation can be attributed to the behaviour of chickens when responding to low temperature. The rationale would be that birds took more time huddled at an early age to generate heat instead of eating. Also, (Yalçin et al., 1997a) reported that three broiler chicken lines, having similar performance in the fall (average temperature $18^{\circ} \mathrm{C}$ ), showed a significant difference in feed intake, BW gain, and FE in summer (average temperature $28^{\circ} \mathrm{C}$ ). Similarly, the genotypes of commercial broilers that gain more weight in the spring tend to gain less weight under the hot conditions of summer (Settar et al., 1999). Hence, the broilers' genotype should be considered in broiler production in subtropical and temperate regions, especially given the increasing proportion of world broiler production in these regions.

\section{CONCLUSION}

The Libyan government has established many projects like (Ghot Al sultan and Tawergha) to improve the productivity of the local breed and cover the increasing demand for broiler meat. These projects used standard broiler parents (Hypeco, Avian, and Shaver breeds), which were selected from temperate climates. Where- 
as the Libyan climate is hot, dry, and humid during summer, moderate- warm in winter with variations between different locations. Therefore, when importing breeds, it needs to consider the interaction between breeds and the location. Furthermore, it essential to evaluate and compare the performance of Hypeco, Avian, and Shaver breeds during the rearing period determining the most suitable breed under local conditions. Finally, the main conclusions of these experimental work should be presented.

\section{REFERENCES}

Adeyinka, I.A., Oni, O.O., Nwagu, B. I., \& Adeyinka, F. D. (2006). Genetic Parameter Estimates of Body Weights of Naked Neck Broiler Chickens. International Journal of Poultry Science, 5 (6): 589-592. DOI: 10.3923/ijps.2006.589.592

Ahaotu, E.O., Patricio, D. R., Ibe, L.C., and Singh, R.R. (2019). Climate Change in Poultry Production System: A Review." Acta Scientific Agriculture 3.9: 113-117. DOI: 10.31080/ASAG.2019.03.0617

Aksit, M., Yalcin, S., Ozkan, S., Metin, K., \& Ozdemir, D. (2006). Effects of temperature during rearing and crating on stress parameters and meat quality of broilers. Poultry Science, $\quad 85 \quad$ (11): $\quad$ 1867-1874. Doi:10.1093/ps/85.11.1867

Akyuz, A. (2009). Effects of some climates parameters of environmentally uncontrollable broiler houses on broiler performance. Journal of Animal and Veterinary Advances, 8 (12): 2608-2612.

Babinszky, L., Halas, V., \& Verstegen, M. W. (2011). Impacts of climate change on animal production and quality of animal food. In J, Blanco. and $\mathrm{H}$, Kheradmand. Climate change -socioeconomic effects products (pp. 165-190). DOI: $10.5772 / 23840$

Hypeco - broiler parentstock. Nuland/Holland, 1987.
Liu, L., Ren, M., Ren, k., Jin, Y., \& Yan, M. (2020). Heat stress impacts on broiler performance: a systematic review and metaanalysis. Retrieved from https://www.sciencedirect.com/science/arti cle/pii/S0032579120305575

Mengesha, M. (2011). Climate change the preference of rearing poultry for the demands of protein foods. Asian Journal of Poultry Science, 5:135-143. DOI: 10.3923/ajpsaj.2011.135.143

Molapo, S.M. (2011). Effects of season and restricted feeding during rearing and laying in productive and reproductive performance of Koekoek chickens in Lesotho. (Doctoral dissertation). University of Pretoria.

Okonkwo, S., and Ahaotu, E.O. (2019). Management of Laying Birds in Deep Litter and Battery Cage Systems Inorlu Local Government Area of Imo State, Nigeria: A Comparative Study. International Journal of Research in Agriculture and Forestry, 6: 21-29

Pakdel, A., Van Arendonk, J. A. M., Vereijken, A. L. J. \& Bovenhuis, H.(2005). Genetic parameters of ascites-related traits in broilers: correlations with feed efficiency and carcase traits', British Poultry Science, 46: 1, 43 -53, DOI: $10.1080 / 00071660400023805$

Plavnik, I., \& Yahav, S. (1998). Effect of environmental temperature on broiler chickens subjected to growth restriction at an early age. Poultry Science, 77: 870-872. doi: $10.1093 / \mathrm{ps} / 77.6 .870$

Settar, P., Yalcin, S., Turkmut, L., Ozkan, S. and Cahane, C. (1999) .Season by genotype interaction related to broiler growth rate and heat tolerance. Poultry Science, $78: 1353-1358 . \quad$ DOI:10.1093/ps/ 78.10 .1353

Shaver Starbro Grandparent Mangment Guide. Holland, 1994. 
Statosoft, inc., Tulsa, Ok: STATISTICA, Version 8 (2007)

Trewartha, G., \& Horn, L. (1980). An Introduction to Climate-McGraw-Hill. New York, $416 \mathrm{pp}, 10$.

Yalcin, S., Settar, P., Ozkan, S., and Cahaner, A. (1997a). Comparative evaluation of three commercial broiler stocks in hot versus temperate climates. Poultry Science, 76: 921 - 929. DOI: 10.1093/ps/76.7.921

Yalcin, S., Testik, A., Ozkan, S., Settar, P., Celen, F., \& Cahaner, A. (1997b). Performance of Naked Neck and Normal Broilers in Hot, Warm, and Temperate Climates. Poultry science, 76:930-937. DOI: $10.1093 / \mathrm{ps} / 76.7 .930$ 


\section{التفاعل الوراثي البيئي للوزن سبعة أسابيع لسلالات الدواجن تحت الظروف الليبية \\ رياب فتحي الارناوي"، سالم علي بوزريدة وفتحي علي عطية

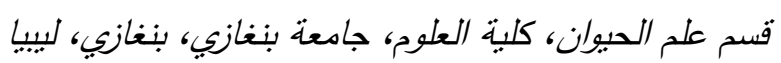

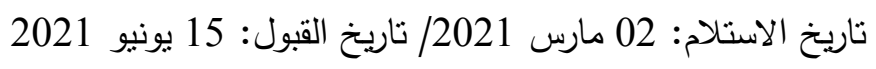
https://doi.org/10.54172/mjsc.v36i2.57:Doi

المستخلص: هدفت الدراسة لبحث التفاعل بين سلالات الدواجن والبيئة لوزن الجسم عند عمر سبعة أسابيع تحت الظروف الليبية،

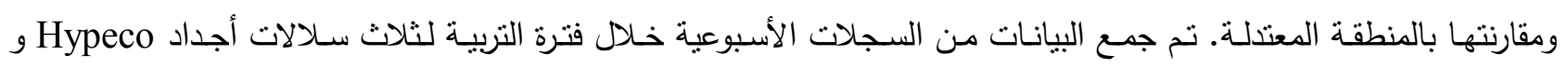

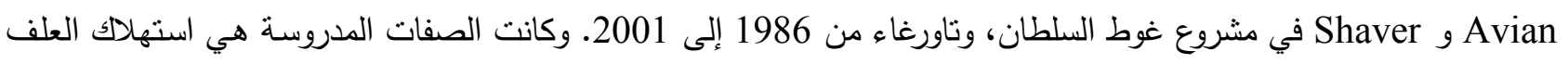
اليومي، استهلاك العلف التراكمي، وزن الجسم، نسبة استهلاك العلف، ومعدل النفوق. نم استخدام النموذج الرياضي لتحليل بيانات

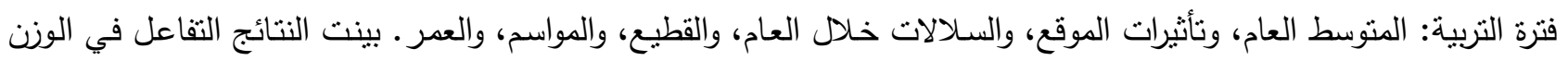

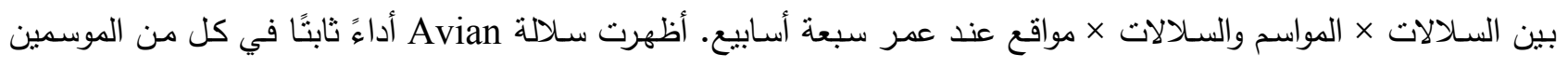

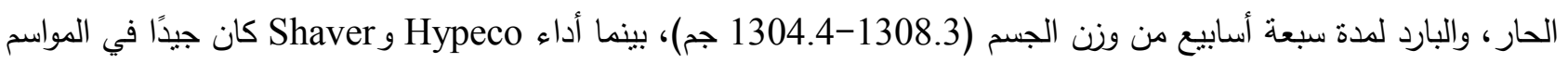

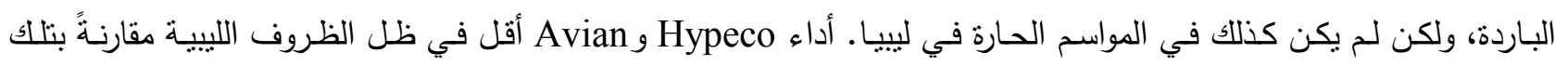

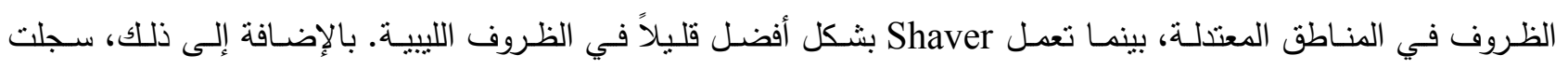

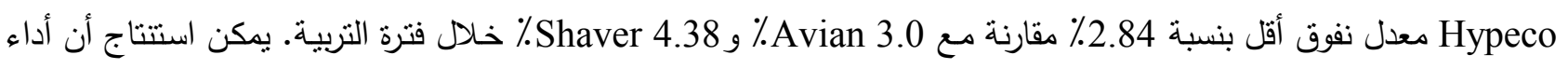
سلالات الأجداد في ظل الظروف الليبية تتأثز بالطقس، والإدارة. الكلمات المفتاحية :النمط الوراتي، سلالات الدواجن، التفاعل، وزن الجسم، الظروف الليبية 